\title{
EFFECT OF DIFFERENT BORON APPLICATION ON COTTON YIELD COMPONENTS AND FIBER QUALITY PROPERTIES
}

\author{
Emine KARADEMIR $^{1^{*}}$, C. KARADEMIR ${ }^{1}$ \\ E-mail: eminekarademir@siirt.edu.tr
}

Received: Nov. 14, 2019. Revised: Jan. 19, 2020. Accepted: Jan. 25, 2020. Published online: Mar. 06, 2020

\begin{abstract}
This study was carried out to determine the effect of different boron application methods on cotton yield, plant growth and fiber technological properties. The study was conducted at Siirt University Faculty of Agriculture Department of Field Crops experimental area as randomized complete block design with four replications in 2018. Stoneville 468 cotton variety and boron liquid foliar fertilizer were used as material. Seven different boron applications were performed as (Control, $1000 \mathrm{cc} \mathrm{ha}^{-1}$ at pre-flowering stage, $2000 \mathrm{cc} \mathrm{ha}^{-1}$ at preflowering stage, $1000 \mathrm{cc} \mathrm{ha}^{-1}$ at flowering stage, $2000 \mathrm{cc} \mathrm{ha}^{-1}$ at flowering stage and $1000 \mathrm{cc} \mathrm{ha}^{-1}$ at boll formation stage, $2000 \mathrm{cc} \mathrm{ha}{ }^{-1}$ at boll formation stage). The results of statistical analysis showed that there were significant differences between applications methods in terms of plant height and number of monopodial branches. But there were non-significant differences in terms of number of sympodial branches, number of first node
\end{abstract}

of sympodial branch, number of nodes, height/node ratio, number of bolls, boll weight, seed cotton weight of per boll, number of seeds per boll, first picking percentage, 100 seeds weight, ginning percentage, seed cotton yield and fiber technological characteristics. In conclusion different application methods of boron increased plant height and number of monopodial branches of cotton when applied as 1000 and $2000 \mathrm{cc} \mathrm{ha}^{-1}$ at preflowering stages.

Keywords: cotton; plant nutrition; plant growth; seed cotton yield.

\section{INTRODUCTION}

Boron is one of the micronutrient that regulates the growth and development of plants and is the only element that is close to each other with the amount that causes deficiency symptoms and the toxic

\footnotetext{
${ }^{1}$ Siirt University, Faculty of Agriculture, Department of Field Crops, Siirt, Turkey
} 


\section{Emine KARADEMIR, C. KARADEMIR}

effect to plants in all necessary nutrients (Çelik et al., 1998). Boron is at the top of the $3 \mathrm{~A}$ group of the periodic system. It is the only nonmetal element in micro plant nutrients. It's atomic number is 5 and the atomic weight is 10,81 . Since it has a tendency to oxygen, the oxygen compounds of boron are quite abundant in the form of sodium and calcium borates. The most abundant boron compound is boric acid $\left(\mathrm{H}_{3} \mathrm{BO}_{3}\right)$ and borax (Adriano, 1986).

Most of the researches are focused on boron deficiency, since there is a lack of in the soil of the Earth. On the other hand, in our country, which has the richest boron soils in the world, there is an excess of boron and boron toxicity caused by this in growing plants. Boron is immobile in plant organs. As the plant loses water by transpiration, boron is transported to the peaks of xylem transmission bundles in the plant and accumulates there. Boron accumulated in plant leaves causes toxic effects over time. Some plants remove excess boron from the leaves by guttation to prevent this toxicity (Marschner, 1995).

As mentioned above, Turkey soil's is rich in terms of boron. However, the excess boron in soils has a limiting effect on plant growth and development due to its toxic effects. The presence of more than $5 \mathrm{mg} / \mathrm{kg}$ of boron in the soil leads to excess boron (Rashid and Ryan, 2004). In this respect, boron toxicity and zinc ( $\mathrm{Zn})$ deficiency are among the most common micronutrient problems encountered in Central Anatolia (Çakmak et al., 1995). Boron is taken up by plants both by active and passive absorption. It is generally thought that it is taken as boric acid by passive absorption, and borate anion by active absorption. Debates about the passive or active uptake of boron have been continued by many researchers for many years (Marschner, 1995; Kaçar and Katkat, 1999). It is reported that boron is necessary to transport carbohydrates in plants both directly and indirectly, and is involved in the differentiation and maturation of cells (Karaman, 2012). Boron is an important element in cell division, elongation and growth in plants. Takes part in carbohydrate metabolism. It helps the movement of sugars in the plant. It facilitates the transport of sugar-borate complexes to other organs and cells of plants. It also prevents excessive polymerization in sugar synthesis. Boron is an important element for the synthesis of nucleic acids (RNA) and its deficiency is negatively affecting protein synthesis. Therefore, boron application increases protein synthesis. Polyphenolase has the effect of regulating oxidation due to enzyme activity. Boron increases phosphorus and calcium uptake in plants.

Boron also has an important effect on lignin formation, cell wall formation, respiration, IAA (indole acetic acid) and phenol metabolisms and structural and functional properties of biological membranes. Since boron is an immobil nutrient in the plant, symptoms of deficiency are 


\section{EFFECT OF FOLIAR BORON APPLICATION ON COTTON}

primarily seen in young organs. The growth points are manifested by pauses in the formation of yellow and red colors and yellowish color changes occur in the leaf color. The lack of boron in cotton causes small and deformed boll, leads to a decrease in fruit set, resulting in reduced cotton yield and fiber yield (Roberts et al., 2000). One of the most prominent features of deficiency symptoms is the death of some of the meristematic cells. In case of boron deficiency terminal bud dies, shells crack and flowering decreases. Problems arise in the xylem system and the transmission bundles are damaged. Root formation weakens and cell disintegration occurs in the roots. Lack of boron during flowering and fruit formation period also leads to shedding (Rosolem and Bogiani, 2011). Pollen germination and pollen tube morphology also are being affected by boron deficiency (Viswanathan, 1995). It is important to apply boron to leaf or soil in order to eliminate deficiency. Boron can be applied to both the soil and the leaves. It is stated that the application before the flowering will be beneficial for the leaves. Boron toxicity manifests itself as necrosis starting from leaf ends and edges and progressing from the side veins to the middle leaf veins. Symptoms spread to the edges of the leaf and middle vein over time, leaves later look roasted and shed early (Karaman, 2012).

Oosterhuis and Brown (2003) reported that the information about boron is based on the studies done
30 years ago and that no modern varieties have been studied. They also stated that some information is contradictory, some literature has stated that the effect on yield is significant and others are insignificant and some studies are needed to understand the effect of boron on physiology.

It is known that boron has a significant effect on plant development and physiological processes, but studies on boron in cotton plants seem to be insufficient. This study was carried out to determine the effect of different applications of boron on yield, yield components, plant growth and fiber quality properties in cotton.

\section{MATERIAL AND METHODS}

The study was conducted in Siirt University, Faculty of Agriculture and Department of Field Crops. Stoneville 468 cotton variety and BOR-8 liquid leaf fertilizer were used as material. The study was conducted in randomized block design with four replications and 7 different applications were used in the experiment.

Treatments: 1) Control; 2) $1000 \mathrm{cc}$ $\mathrm{ha}^{-1}$ at pre-flowering stage; 3) $2000 \mathrm{cc} \mathrm{ha}^{-1}$ at pre-flowering stage; 4) $1000 \mathrm{cc} \mathrm{ha}^{-1}$ at flowering stage; 5) $2000 \mathrm{cc} \mathrm{ha}^{-1}$ at flowering stage; 6) $1000 \mathrm{cc} \mathrm{ha}^{-1}$ at boll formation stage; 7) $2000 \mathrm{cc} \mathrm{ha}^{-1}$ at boll formation stage.

Before sowing, the soil samples were taken from $0-30 \mathrm{~cm}$ depth and analyzed at Siirt University laboratory. The results of soil analysis can be shown at Table 1. Sowing was made with cotton drill machine on 4 May 2018, in sowing each plot consisted of four rows with $6 \mathrm{~m}$ length, the distance between rows was 
$0.70 \mathrm{~m}$. In the experiment, all maintenance operations were done on time. All plots received $140 \mathrm{~kg} \mathrm{ha}^{-1} \mathrm{~N}$ and $60 \mathrm{~kg} \mathrm{ha}^{-1} \mathrm{P}_{2} \mathrm{O}_{5}$. Half of the nitrogen and all phosphorus were applied at sowing time and the remaining $\mathrm{N}$ was given as ammonium nitrate $(33 \%)$ at the squaring stage before the first irrigation. Thinning performed when plants were $10-15 \mathrm{~cm}$ high. The experiment was hoed three times by hand and four times with a machine.

Herbs and insects were monitored throughout the experiment and no pesticides were necessary during growing season. Drip irrigation system were used for irrigation, plots were irrigated for the first time at squaring stage and irrigation terminated at $10 \%$ boll opening stage.

From the Fig. 1 and Fig. 2 it can be seen that the average, maximum and minimum temperature in the experimental year was higher than long term period and average rainfall in the May and October was higher than long term periods. The plots were harvested twice by hand for yield determination on 3 October 2018 and second on 01 November 2018. Seed cotton yield was calculated based on the hand-harvests.
Table 1 - Soil characteristics
of experimental area

\begin{tabular}{lll}
\hline Texture & Clay & \\
\hline $\mathrm{pH}$ & 7.98 & $\begin{array}{l}\text { Slightly } \\
\text { alkali }\end{array}$ \\
\hline $\mathrm{EC}(\mathrm{mS} / \mathrm{cm})$ & 0.363 & Saltless \\
\hline Lime $\left.(\% \mathrm{CaCO})_{3}\right)$ & 13.02 & Limy \\
\hline Organic Matter $(\%)$ & 1.31 & Low \\
\hline $\mathrm{N}(\%)$ & 0.082 & Low \\
\hline $\mathrm{P}(\mathrm{ppm})$ & 7.47 & Low \\
\hline $\mathrm{K}(\mathrm{me} / 100 \mathrm{~g})$ & 0.98 & High \\
\hline $\mathrm{Fe}(\mathrm{ppm})$ & 5.70 & Adequate \\
\hline $\mathrm{Cu}(\mathrm{ppm})$ & 2.63 & Adequate \\
\hline $\mathrm{Zn}(\mathrm{ppm})$ & 0.23 & Low \\
\hline $\mathrm{Mn}(\mathrm{ppm})$ & 6.04 & Low \\
\hline
\end{tabular}

After the harvest, seed cotton samples were ginned on a mini-laboratory roller-gin for lint percentage. Fiber samples (which are taken from first harvesting) were then analyzed in GAP International Agricultural Research and Training Center (GAPUTAEM)'s lint analysis laboratory for fiber quality properties by High Volume Instrument (HVI 1000). Statistical analysis was performed using JUMP 5.0.1 statistical software and the means were grouped with $\operatorname{LSD}_{(0.05)}$ test.

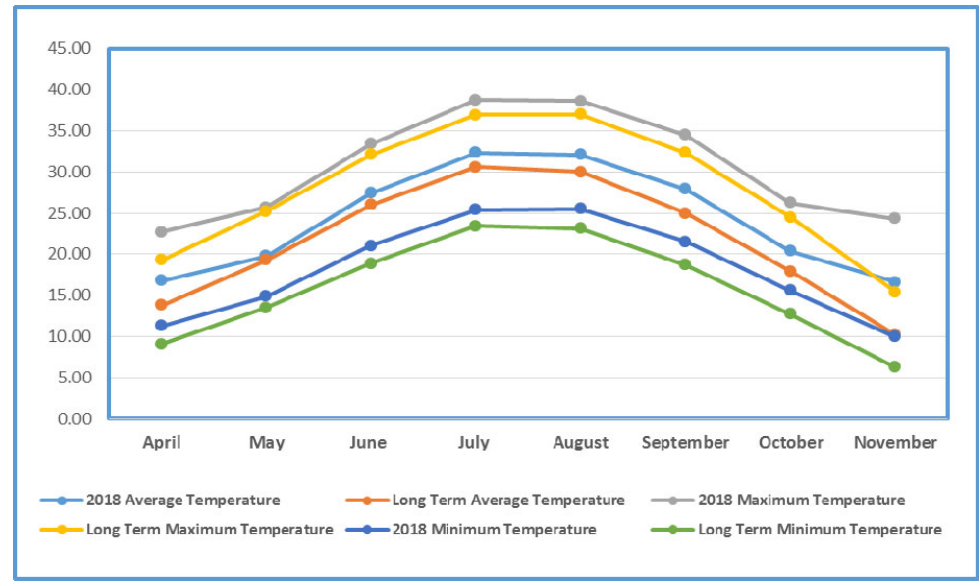

Figure 1 - Average, maximum and minimum temperature $\left({ }^{\circ} \mathrm{C}\right)$ during experimental year and long term period 


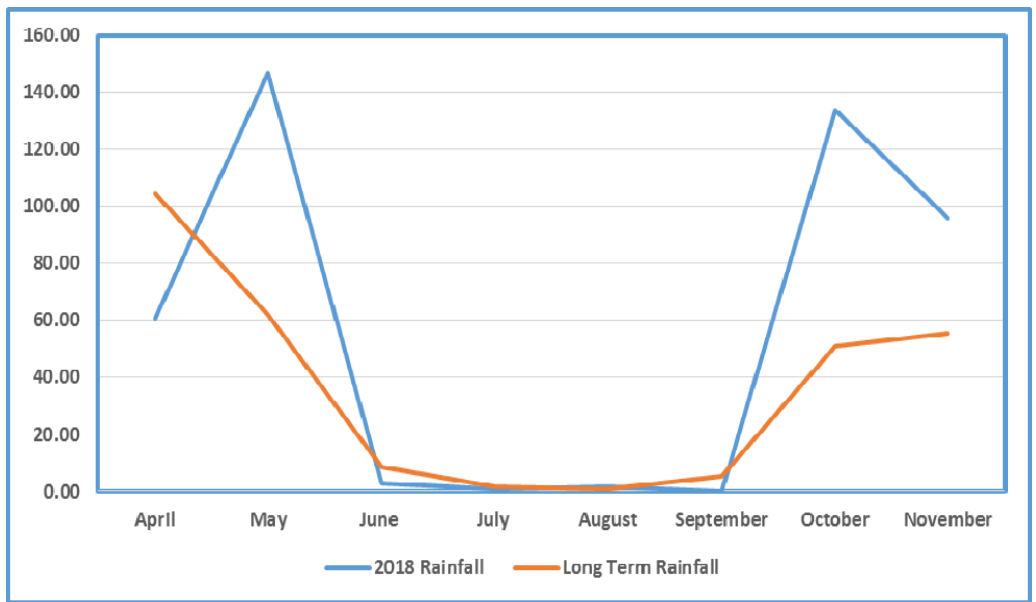

Figure 2 - Average rainfall $(\mathrm{mm})$ during experimental year and long term period

\section{RESULTS AND DISCUSSION}

The differences between investigated traits and LSD ${ }_{(0.05)}$ test results are given in Tables 2-4.

The differences between the treatments with respect to plant height were statistically significant $(p<0.05)$. According to the Table 2, plant height ranged between 69.44 to $77.55 \mathrm{~cm}$. The average plant height of treatments was $72.55 \mathrm{~cm}$. The highest plant height values were obtained from $2000 \mathrm{cc} \mathrm{ha}^{-1}$ boron application to leaves at pre-flowering (PF) stage as $77.55 \mathrm{~cm}$, followed by $1000 \mathrm{cc} \mathrm{ha}^{-1}$ at the same stage as $74.88 \mathrm{~cm}$ and the lowest plant height values were obtained from $1000 \mathrm{cc} \mathrm{ha}$ at flowering (FL) stage as $69.44 \mathrm{~cm}$.

The results of this study is compromise with the results of Oosterhuis (2001), Zhao and Oosterhuis (2008), Ahmed et al. (2013), Kumar et al. (2018), who reported the significance effect of foliar boron application on plant height; on the other hand, Şimşek (2006) and Rahman et al. (2018) reported that boron application did not affect plant height significantly.

The differences between the treatments with respect to number of monopodial branches (NMB) were significant $(p<0.01)$. According to the Table 2, NMB ranged between 1,33 to 2,44 number plant $^{-1}$. The average NMB of treatments were 1,86 . The highest NMB values were obtained from $2000 \mathrm{cc} \mathrm{ha}^{-1}$ boron application to leaves at PFL stage as 2.44, followed by $1000 \mathrm{cc} \mathrm{ha}^{-1}$ at the same stage as 2.10 and the lowest NMB values were obtained from $1000 \mathrm{cc} \mathrm{ha}^{-1}$ at BF stage as 1.33 (Table 2). Previous researchers reported that NMB increased by application of boron (Şimşek, 2006), while Kumar et al., (2018) reported non-significant association for NMB. 
Table 2 - Average values and statistical groups of investigated traits

\begin{tabular}{|c|c|c|c|c|c|c|c|}
\hline Treatmens & $\begin{array}{l}\text { PH } \\
(\mathrm{cm})\end{array}$ & $\begin{array}{c}\text { NMB } \\
\text { (number }^{-1} \\
\text { plant }^{-1} \text { ) }\end{array}$ & $\begin{array}{c}\text { NSB } \\
\text { (number } \\
\text { plant }^{-1} \text { ) }\end{array}$ & $\begin{array}{c}\text { NNFFB } \\
\text { (number }^{-1} \\
\text { plant }^{-1} \text { ) }\end{array}$ & $\begin{array}{c}\text { NNPP } \\
\text { (number } \\
\text { plant }^{-1} \text { ) }\end{array}$ & $\begin{array}{c}\text { HNR } \\
\text { (number }^{\text {plant }}{ }^{-1} \text { ) }\end{array}$ & $\begin{array}{c}\text { NB } \\
\text { (number }^{\text {plant }}{ }^{-1} \text { ) }\end{array}$ \\
\hline 1. Control & $\begin{array}{c}70.99 \\
\text { bc }\end{array}$ & $1.66 \mathrm{bc}$ & 11.77 & 5.55 & 17.00 & 4.17 & 14.99 \\
\hline 2. PFL/1000 cc ha-1 & $\begin{array}{c}74.88 \\
a b \\
\end{array}$ & $2.10 a b$ & 11.99 & 5.77 & 17.33 & 4.32 & 16.00 \\
\hline 3. PFL/2000 cc ha ${ }^{-1}$ & $\begin{array}{c}77.55 \\
\mathrm{a}\end{array}$ & $2.44 \mathrm{a}$ & 12.44 & 5.88 & 17.44 & 4.45 & 17.77 \\
\hline 4. FL/1000 cc ha-1 & $\begin{array}{c}69.44 \\
\mathrm{C}\end{array}$ & $1.88 \mathrm{~b}$ & 12.10 & 4.77 & 16.77 & 4.14 & 14.33 \\
\hline 5. FL/2000 cc ha- & $\begin{array}{c}74.10 \\
a b c\end{array}$ & $1.99 a b$ & 12.77 & 5.33 & 17.21 & 4.30 & 18.22 \\
\hline 6. BF/1000 cc ha ${ }^{-1}$ & $\begin{array}{c}69.66 \\
\mathrm{c} \\
\end{array}$ & $1.33 \mathrm{c}$ & 12.88 & 5.55 & 16.77 & 4.15 & 14.33 \\
\hline 7. BF/2000 cc ha ${ }^{-1}$ & $\begin{array}{c}71.22 \\
\text { bc }\end{array}$ & $1.66 \mathrm{bc}$ & 12.44 & 5.33 & 16.77 & 4.24 & 14.66 \\
\hline Mean & 72.55 & 1.86 & 12.34 & 5.45 & 17.04 & 4.25 & 15.75 \\
\hline CV $(\%)$ & 4.45 & 17.74 & 5.83 & 9.90 & 3.16 & 4.94 & 17.39 \\
\hline $\operatorname{LSD}(0.05)$ & $4.78^{*}$ & $0.48^{* *}$ & ns & ns & ns & ns & Ns \\
\hline
\end{tabular}

PFL: Pre-flowering; FL: Flowering; BF: Boll formation; PH: Plant height; NMB: Number of monopodial branches; NSB: Number of sympodial branches; NNFFB: Number of first fruiting branches; NNPP: Number of nodes per plant; HNR: Height/node ratio; NB: Number of boll.

The differences between the treatments with respect to number of sympodial branches (NSB) were nonsignificant. According to the Table 2, NSB ranged between 11.77 to 12.88 number plant ${ }^{-1}$. The average NSB of treatments were 12.34 number plant ${ }^{-1}$. The highest NSB values were obtained from $1000 \mathrm{cc} \mathrm{ha}^{-1}$ boron application to leaves at BF stage, while the lowest NSB values were obtained from control (Table 2). The results of this study is compromise with the results of Şimşek (2006), who reported the non-significance effect of foliar boron application on NSB; on the other hand, Kumar et al. (2018) and More et al. (2018) reported that boron application affected NSB significantly.

The differences between the treatments with respect to number of node to the first fruiting branch (NNFFB) were non-significant. According to the Table 2, NNFFB ranged between 4.77 to 5.88 number plant $^{-1}$. The average NNFFB of treatments were 5.45 number plant ${ }^{-1}$. The highest NNFFB values (5.88) were obtained from $2000 \mathrm{cc} \mathrm{ha} \mathrm{ha}^{-1}$ boron application to leaves at PFL stage, while the lowest NNFFB values were obtained from $1000 \mathrm{cc} \mathrm{ha}^{-1}$ at FL stage (Table 2). The results of this study is compromise with the results of Sohair et al. (2014), who reported 


\section{EFFECT OF FOLIAR BORON APPLICATION ON COTTON}

the non-significance effect of foliar boron application on NNFFB.

The differences between the treatments with respect to number of node (NN) were non-significant. According to the Table 2, NN ranged between 16.77 to 17.44 number plant ${ }^{-1}$. The average $\mathrm{NN}$ of treatments were 17.04 plant $^{-1}$. The highest $\mathrm{NN}$ values (17.44) were obtained from $2000 \mathrm{cc}$ $\mathrm{ha}^{-1}$ boron application to leaves at PFL stage, while the lowest $\mathrm{NN}$ values were obtained from $1000 \mathrm{cc} \mathrm{ha}^{-1}$ at FL, $1000 \mathrm{cc} \mathrm{ha}^{-1}$ at $\mathrm{BF}$ and $2000 \mathrm{cc}$ $\mathrm{ha}^{-1}$ at BF stages as 16.77 (Table 2). The results of this study is compromise with the results of Dordas (2006) and Bogiani and Rosolem (2012), who reported the non-significance effect of foliar boron application on $\mathrm{NN}$, but not with Ahmed et al. (2013) and Ahmed et al. (2008).

The differences between the treatments with respect to height/node ratio (HNR) were non-significant. According to the Table 2, HNR ranged between 4.14 to 4.45 number plant $^{-1}$. The average HNR of treatments were 4.25 number plant ${ }^{-1}$. The highest HNR values (4.45) were obtained from $2000 \mathrm{cc} \mathrm{ha}^{-1}$ boron application to leaves at PFL stage, while the lowest HNR values were obtained from $1000 \mathrm{cc} \mathrm{ha}^{-1}$ at FL as 4.14 (Table 2). The results of this study is compromise with the results of Ahmet et al. (2013), who reported the non-significance effect of foliar boron application on HNR.

The differences between the treatments with respect to number of boll (NB) were non-significant. According to the Table 2, NB ranged between 14.33 to 18.22 number plant ${ }^{-1}$. The average NB of treatments were 15.75 number plant ${ }^{-1}$. The highest NB values (18.22) were obtained from $2000 \mathrm{cc} \mathrm{ha}^{-1}$ boron application to leaves at FL, followed by $2000 \mathrm{cc} \mathrm{ha}^{-1}$ at PFL stages as 17.77 , while the lowest NB values were obtained from $1000 \mathrm{cc} \mathrm{ha}^{-1}$ at FL and $1000 \mathrm{cc} \mathrm{ha}^{-1}$ at BF stages as 14.33 (Table 2).

The results of this study is compromise with the results of Heitholt (1994), who reported that boron application not increasing NB, but not with Dordas (2006), Rashidi and Gholami (2011), Rashidi and Seilsepour (2011), Kumar et al. (2018), who reported the significance effect of foliar boron application on NB.

From Table 3 it can be seen that boll weight values varied between 6.51 and $6.95 \mathrm{~g}$ depending on the applications.

Although there was no significant difference between the applications, the highest boll weight value was obtained from the application of boron to the leaf preflowering (2000 cc ha) $(6.95 \mathrm{~g})$, while the lowest value (6.51 g) was obtained from the application to the leaf at boll formation period (1000 cc ha). Findings obtained from this research, which is foliar boron applications, do not have a significant effect on boll weight in cotton, are in line with Dordas (2006), Görmüş (2005), Rashidi and Gholami (2011), Ahmed et al. (2013), Kumar et al. (2018). 
Emine KARADEMIR, C. KARADEMIR

Table 3 - Average values and statistical groups of some investigated traits

\begin{tabular}{|c|c|c|c|c|c|c|c|}
\hline Treatments & $\begin{array}{l}\text { BW } \\
(g)\end{array}$ & $\begin{array}{c}\text { SBSCW } \\
\text { (g) }\end{array}$ & $\begin{array}{c}\text { NSPB } \\
\text { (number } \\
\text { plant }^{-1} \text { ) }\end{array}$ & $\begin{array}{c}100 \mathrm{SW} \\
(\mathrm{g})\end{array}$ & $\begin{array}{c}\text { FPP } \\
(\%)\end{array}$ & $\begin{array}{l}\text { GP } \\
(\%)\end{array}$ & $\begin{array}{c}\text { SCY } \\
\left(k^{-1} a^{-1}\right)\end{array}$ \\
\hline 1. Control & 6.82 & 5.38 & 27.00 & 9.71 & 82.74 & 46.20 & 4362.70 \\
\hline 2. PFL/1000 cc ha- ${ }^{-1}$ & 6.84 & 5.35 & 27.65 & 9.81 & 81.44 & 45.65 & 4558.60 \\
\hline 3. $\mathrm{PFL} / 2000 \mathrm{cc} \mathrm{ha}^{-1}$ & 6.95 & 5.51 & 26.70 & 9.55 & 79.02 & 45.50 & 4505.00 \\
\hline 4. $\mathrm{FL} / 1000 \mathrm{cc} \mathrm{ha}^{-1}$ & 6.92 & 5.45 & 28.08 & 9.78 & 73.69 & 46.00 & 4567.50 \\
\hline 5. FL/2000 cc ha ${ }^{-1}$ & 6.79 & 5.35 & 26.98 & 9.75 & 82.34 & 45.65 & 4560.70 \\
\hline 6. $\mathrm{BF} / 1000 \mathrm{cc} \mathrm{ha}^{-1}$ & 6.51 & 5.23 & 26.87 & 9.67 & 82.13 & 45.95 & 4385.10 \\
\hline 7. $\mathrm{BF} / 2000 \mathrm{cc} \mathrm{ha}^{-1}$ & 6.65 & 5.25 & 28.48 & 9.49 & 79.28 & 44.95 & 4784.50 \\
\hline Mean & 6.78 & 5.36 & 27.39 & 9.68 & 80.09 & 45.70 & 4532.00 \\
\hline CV (\%) & 3.68 & 3.35 & 10.58 & 4.64 & 4.64 & 1.53 & 19.53 \\
\hline $\operatorname{LSD}(0.05)$ & ns & ns & ns & ns & ns & ns & ns \\
\hline
\end{tabular}

PFL: Pre-flowering; FL: Flowering; BF: Boll formation; BW: Boll weight; SBCW: Single boll cotton weight; NSPB: Number of seed per boll; 100 SW: 100 seed weight; FPP: First picking percentage; GP: Ginning percentage; SCY: Seed cotton yield.

From Table 3 it can be seen that single boll seed cotton weight values varied between 5.23 and $5.51 \mathrm{~g}$ depending on the applications. Although there was no significant difference between the applications, the highest single boll seed cotton weight value $(5.51 \mathrm{~g})$, was obtained from the application of boron to the leaf pre-flowering (2000 cc ha), while the lowest value $(5.23 \mathrm{~g})$ was obtained from the application to the leaf at boll formation period (1000 cc ha). Findings obtained from this research, which is foliar boron applications, do not have a significant effect on single boll seed cotton weight in cotton, are in line with Seilsepour and Baniaini (2011), but not consistent with the findings of Şimşek (2006) and Rashidi and Gholami (2011).
From Table 3 it can be seen that number of seeds per boll values varied between 26.70 and 28.48 number plant $^{-1}$ depending on the applications. Although there was no significant difference between the applications, the highest seeds per boll value ( 28.48 number plant ${ }^{-1}$ ) was obtained from the application of boron to the leaf at boll formation period (2000 cc ha), while the lowest value (26.70 number plant ${ }^{-1}$ ) was obtained from the application to the leaf at pre-flowering period (2000 cc ha).

From Table 3 it can be seen that 100 seeds weight values varied between 9.49 and $9.81 \mathrm{~g}$ depending on the applications. Although there was no significant difference between the applications, the highest 100 seeds weight value was obtained from the 


\section{EFFECT OF FOLIAR BORON APPLICATION ON COTTON}

application of boron to the leaf preflowering (1000 cc ha) (9.81 g), while the lowest value was obtained from the application to the leaf at boll formation period (2000 cc ha) (9.49 g). Findings obtained from this research, which is foliar boron applications, do not have a significant effect on 100 seeds weight in cotton, are not consistent with the findings of Zare et al. (2013), who reported that the 1000 grain weight of wheat decreased by application of boron.

From Table 3 it can be seen that first picking percentage values varied between 73.69 and $82.74 \%$ depending on the applications. Although there was no significant difference between the applications, the highest first picking percentage value was obtained from the Control $(82.74 \%)$, while the lowest value $(73.69 \%)$ was obtained from the application to the leaf at flowering period at $1000 \mathrm{cc} /$ ha. Findings obtained from this research, which is foliar boron applications, do not have a significant effect on first picking percentage in cotton, are in line with Eleyan et al., (2014).

From Table 3 it can be seen that ginning percentage values varied between 44.95 and $46.20 \%$ depending on the applications. Although there was no significant difference between the applications, the highest ginning percentage value was obtained from control $(46.20 \%)$, while the lowest value was obtained from the application to the leaf at boll formation period $(2000 \mathrm{cc}$ ha) $(44.95 \%)$. Findings obtained from this research, which is foliar boron applications, do not have a significant effect on ginning percentage in cotton, are in line with Abid et al. (2007), but not consistent with the findings of Ahmad et al. (2009) and Rahman et al. (2018).

From Table 3 it can be seen that seed cotton yield varied between 4362.70 to $4784.50 \mathrm{~kg} \mathrm{ha}^{-1}$ depending on the applications.

Although there was no significant difference between the applications, the highest seed cotton yield (4784.50 kg ha $\left.{ }^{-1}\right)$ was obtained from the application to the leaf at boll formation period (2000 cc / ha), while the lowest value was obtained from control as $4362.70 \mathrm{~kg} \mathrm{ha}^{-1}$.

Findings obtained from this research, which is foliar boron applications, do not have a significant effect on seed cotton yield in cotton, are in line with Oosterhuis and Brown (2003) and Oosterhuis (2001), but not consistent with the findings of Rashidi and Seilsepour (2011) and Mooro et al. (2000), who reported that boron application increased yield as 19 and $22 \%$.

From the Table 4, it is seen that there is no significant difference between the applications in terms of fiber quality properties and boron applications did not create a significant difference on all of the fiber quality properties examined. 
Emine KARADEMIR, C. KARADEMIR

Table 4 - Average values and statistical groups of fiber quality properties

\begin{tabular}{|c|c|c|c|c|c|c|c|c|}
\hline Treatments & FF (mic.) & $\begin{array}{c}\mathrm{FL} \\
(\mathrm{mm})\end{array}$ & $\begin{array}{l}\text { FSTR } \\
\text { (g/tex) }\end{array}$ & $\begin{array}{l}\text { ELG } \\
(\%)\end{array}$ & $\begin{array}{l}\text { UNF } \\
(\%)\end{array}$ & $\begin{array}{l}\text { SFI } \\
(\%)\end{array}$ & $\begin{array}{l}\text { RF } \\
\text { (Rd) }\end{array}$ & $\begin{array}{l}\text { YLW } \\
(+b)\end{array}$ \\
\hline 1. Control & 5.02 & 28.96 & 29.62 & 6.82 & 85.42 & 5.92 & 79.87 & 8.87 \\
\hline 2. PFL/1000 cc ha-1 & 5.01 & 28.90 & 29.27 & 6.75 & 85.00 & 6.30 & 80.25 & 8.65 \\
\hline 3. PFL/2000 cc ha ${ }^{-1}$ & 4.84 & 29.20 & 29.90 & 6.90 & 85.27 & 6.07 & 79.37 & 8.90 \\
\hline 4. FL/1000 cc ha-1 & 5.03 & 28.62 & 29.17 & 6.90 & 84.92 & 5.97 & 78.27 & 8.67 \\
\hline 5. FL/2000 cc ha ${ }^{-1}$ & 5.01 & 28.86 & 28.32 & 6.97 & 85.15 & 6.05 & 79.12 & 8.72 \\
\hline 6. $\mathrm{BF} / 1000 \mathrm{cc} \mathrm{ha}^{-1}$ & 4.91 & 27.90 & 29.57 & 6.42 & 85.42 & 6.15 & 80.17 & 9.22 \\
\hline 7. $\mathrm{BF} / 2000 \mathrm{cc} \mathrm{ha}^{-1}$ & 4.96 & 29.09 & 30.12 & 6.90 & 86.00 & 5.32 & 79.52 & 8.65 \\
\hline Mean & 4.97 & 28.79 & 29.42 & 6.81 & 85.31 & 5.97 & 79.51 & 8.81 \\
\hline $\mathrm{CV}(\%)$ & 3.62 & 2.57 & 6.49 & 5.13 & 1.51 & 15.24 & 1.99 & 4.54 \\
\hline $\operatorname{LSD}(0.05)$ & ns & ns & ns & ns & ns & ns & ns & ns \\
\hline
\end{tabular}

PFL: Pre-flowering; FL: Flowering; BF: Boll formation; FF: Fiber fineness; FL: Fiber length; FSTR: Fiber strength; ELG: Elongation; UNF: Uniformity; SFI: Short fiber index; RF: Reflectance; YLW: Yellowness.

\section{CONCLUSIONS}

In this study, where seven different application methods of boron were compared, it was found that there were differences between the applications in terms of plant height and number of monopodial branches at statistical significance level. Number of sympodial branches, number of nodes for first fruiting branch, number of nodes, height / nod ratio, number of boll, boll weight, single boll seed cotton weight, number of seeds per boll, first picking percentage, 100 seeds weight, ginning percentage and seed cotton yield between applications differences were not significant. It was determined that boron application methods had no significant effect on fiber quality properties of cotton; $2000 \mathrm{cc} \mathrm{ha}^{-1}$ boron in the pre-flowering period and $1000 \mathrm{cc} \mathrm{ha}^{-1}$ boron in the preflowering period increased the plant height and number of monopodial branches in cotton, respectively.

Acknowledgement. This study was supported by Research Fund of the Siirt University.Projectcode:2016-Sİ̈FEB-25. We would like to thank for their support.

\section{REFERENCES}

Abid, M., Ahmed, N., Ali, A., Chaudhry, M.A. \& Hussain, J. (2007). Influence of soil-applied boron on yield, fiber quality and leaf boron contents of cotton (Gossypium hirsutum L.) . J.Agri.Soc. Sci., 1 (3): 7-10.

Adriano, D.C. (1986). Trace elements in the terrestrial environment, pp. 73105, Springer-Verlag, New York. 


\section{EFFECT OF FOLIAR BORON APPLICATION ON COTTON}

Ahmad, S., Akhtar, L.H., Ahmad, S., Iqbal, N. \& Nasım, M. (2009). Cotton (Gossypium hirsutum L.) varieties responded differently to foliar applied boron in terms of quality and yield. Soil Environ, 28 (1): 88-92.

Ahmed, N., Abid, M. \& Ahmad, F. (2008). Boron toxicity in irrigated cotton (Gossypium hirsutum L.). Pak.J.Bot., 40 (6): 2443-2452.

Ahmed, N., Abid, M., Rashid, A., Arıf Ali, M. \& Ammanullah, M. (2013). Boron requirement of irrigated cotton in a Typic haplocambid for optimum productivity and seed composition. Commun.Soil Sci.Plant Anal., 44(8): 1293-1309, DOI: 10.1080/00103624. 2012.756508.

Bogiani, J.C. \& Rosolem, C.A. (2012). Compared boron uptake and translocation in cotton cultivars. Rev. Bras.Ciênc.Solo, 36(5): 1499-1506, DOI: $10.1590 / S 0100-068320120005$ 00014.

Çakmak, I., Kurz, H. \& Marschner, H. (1995). Short-term effects of boron, germanium and highlight intensity on membrane permeability in boron deficient leaves of sunflower. Physiol.Plant., 95(1): 11-18, DOI: 10.1111/j.1399-3054.1995.tb00801.x

Çelik, H., Ağaoğlu, S. Y., Fidan, Y., Maraşalı, B. ve Söylemezoğlu, G. (1998). Genel Bağcılık. Sunfidan A.Ş. Mesleki Kitaplar Serisi:1, Ankara, 182-183.

Dordas, C. (2006). Foliar boron application affects lint and seed yield and improves seed quality of cotton grown on calcareous soils. Nutr.Cycl.Agroecosys., 76(1): 19-28, DOI: $10.1007 / \mathrm{s} 10705-006-9037-7$.

Eleyan, S.E.D., Abodahab, A.A., Abdallah, A.M. \& Rabeh, H.A. (2014). Foliar application of boron and zinc effects on growth, yield and fiber properties of some Egyptian cotton cultivars (Gossypium barbadense L.). IJACS, 7(13): 12741282.
Görmüş, Ö. (2005). Interactive effect of nitrogen and boron on cotton yield and fiber quality. Turk.J.Agric.For., 29(1): 51-59.

Heitholt, J.J. (1994). Supplemental boron, boll retention percentage, ovary carbohydrates and lint yield in modern cotton genotypes. Agron.J., 86(3): 492-497.

Kaçar, B. ve Katkat, A.V. (1999). Bitki Besleme. Uludağ Üniversitesi. Vipaş Yayınları, Bursa, Turkey.

Karaman, M.R. (2012). Bitki Besleme. Gübretaş Rehber Kitaplar Dizisi: 2.

Kumar, S., Kumar, D., Sekhon, K.S. \& Choudhary, O.P. (2018). Influence of levels and methods of boron application on the yield and uptake of boron by cotton in a calcareous soil of Punjab. Commun. Soil Sci. Plant Anal., 49 (4): 499-514, DOI: 10.1080/00103624.2018.1431268

Marschner, H. (1995). Mineral nutrition of higer plants. Academic Press, 2nd Edition, pp. 379-396.

Mooro, A.W., Soomro, A.R., Leghari, A.B., Chang, M.S., Soomro, A.H. \& Runio, G.H. (2000). Effect of boron and zinc micronutrients on seed cotton yield and its components. Pak.J.Biol.Sci., 3(12): 2008-2009, DOI: 10.3923/pjbs.2000.2008.2009.

More, V.R., Khargkharate, V.K., Yelvikar, N.V. \& Matre, Y.B. (2018). Effect of boron and zinc on growth and yield of Bt. cotton under rainfed condition. Int.J. Pure App.Biosci., 6(4): 566-570, DOI: 10.18782/2320-7051.6885.

Oosterhuis, D. (2001). Physiology and nutrition of high yielding cotton in the USA. http://www.ipni.net/PUBLICA TION/IA-BRASIL.NSF/0/B742311E5 3D30E1E83257AA30063F218/\$FIL E/Enc95p18-24.pdf

Oosterhuis, D.M. \& Brown, R.S. (2003). Effect of soil- and foliar-applied boron on the yield of cotton Under two nitrogen regimes. AAES Research, Series 502, pp. 65-66.

Rashid, A. \& Ryan, J.L. (2004). Micronutrient constraints to crop 
production in soils with Mediterranean type characteristics: a review. J. Plant Nutr., 27(6): 959975, DOI: 10.1081/PLN-120037530

Rashidi, M. \& Gholami, M. (2011). Nitrogen and boron effects on yield and quality of cotton (Gossypium hirsutum L.). IRJAS, 1(4): 118-125.

Rashidi, M. \& Seilsepour, M. (2011). Effect of different application rates on boron on yield and quality of cotton (Gossypium hirsutum L.). Middle East J.Sci.Res., 7(5): 758762.

Rahman, M.T., Haque, M.M., Mortuza, M.G G., Hossain, M.S. \& Chakraborty, R. (2018). Influence of foliar boron application on ginning traits, fiber and seed quality of cotton. J.Exp.Agric.Int., 23 (1): 1-6, DOI: $10.9734 / J E A I / 2018 / 41279$

Roberts, R.K., Gersman, J.M. \& Howard, D.D. (2000). Soil-and foliar-applied boron in cotton production: an economic analysis. J.Cotton Sci., 4(3): 171-177.

Rosolem, C.A. \& Bogiani, J.C. (2011). Chapter 7. Physiology of boron stress in cotton. In: Oosterhuis D.M. (Ed.) Stress physiology in cotton, pp.
113-124, The Cotton Foundation, Cordova, TN, USA. pp. 113-124.

Seilsepour, M. \& Baniaini, E. (2011). Investigation of nitrogen and boron effects on cotton properties in Iran (https://www.icac.org/tis/regional_net works/asian_network/meeting_5/doc uments/papers/PapSeilsepourM.pdf)

Şimşek, M.H. (2006). Effect of soil and foliar applied boron on the growth and yield of cotton. Çukurova University, Institute of Natural and Applied Sciences, Department of Field Crops, MSc Thesis. Adana, Turkey.

Viswanathan, K. (1995). Effect of calcium and boron on in vitro pollen germination and pollen tube growth in Asclepias curassavica Linn. Adv. Plant Sci., 8: 293-296.

Zare, M., Zadehbagheri, M. \& Azrpanah, A. (2013). Influence of Potassium and Boron on Some Traits in Wheat (Triticum aestivum Cv. Darab2). Int.J.Biotechnol., 2(8): 141-153.

Zhao, D. \& Oosterhuis, D. (2008). Cotton growth and physiological responses to boron deficiency. J. Plant Nutr., 26(4): 855-867, DOI: 10.1081/PLN120018570. 